\title{
Prenatal Ultrasound Screening for Fetal Anomalies and Outcomes in High-Risk Pregnancies due to Maternal HIV Infection: A Retrospective Study
}

\author{
A. Reitter, ${ }^{1}$ A. U. Stücker, ${ }^{1}$ H. Buxmann, ${ }^{2}$ E. Herrmann, ${ }^{3}$ A. E. Haberl, ${ }^{4}$ \\ R. Schlößer, ${ }^{2}$ and F. Louwen ${ }^{1}$ \\ ${ }^{1}$ Department of Obstetrics and Gynecology, University Hospital Frankfurt, Goethe-University, Theodor Stern Kai 7, \\ 60590 Frankfurt, Germany \\ ${ }^{2}$ Divison of Neonatology, Department of Pediatrics, University Hospital Frankfurt, Goethe-University, Theodor Stern Kai 7 , \\ 60590 Frankfurt, Germany \\ ${ }^{3}$ Department of Biostatistics and Mathematic Modelling, Goethe-University Frankfurt, Theodor Stern Kai 7, 60590 Frankfurt, Germany \\ ${ }^{4}$ Department of Infectious Diseases, University Hospital Frankfurt, Goethe-University, Theodor Stern Kai 7, 60590 Frankfurt, Germany
}

Correspondence should be addressed to A. Reitter; ankereitter@googlemail.com

Received 1 July 2013; Revised 20 August 2013; Accepted 21 August 2013

Academic Editor: Bryan Larsen

Copyright (C) 2013 A. Reitter et al. This is an open access article distributed under the Creative Commons Attribution License, which permits unrestricted use, distribution, and reproduction in any medium, provided the original work is properly cited.

Objective. To assess the prevalence of prenatal screening and of adverse outcome in high-risk pregnancies due to maternal HIV infection. Study Design. The prevalence of prenatal screening in 330 pregnancies of HIV-positive women attending the department for prenatal screening and/or during labour between January 1, 2002 and December 31, 2012, was recorded. Screening results were compared with the postnatal outcome and maternal morbidity, and mother-to-child transmission (MTCT) was evaluated. Results. One hundred of 330 women (30.5\%) had an early anomaly scan, 252 (74.5\%) had a detailed scan at 20-22 weeks, 18 (5.5\%) had a detailed scan prior to birth, and three (0.9\%) had an amniocentesis. In seven cases $(2.12 \%)$, a fetal anomaly was detected prenatally and confirmed postnatally, while in eight $(2.42 \%)$ an anomaly was only detected postnatally, even though a prenatal scan was performed. There were no anomalies in the unscreened group. MTCT occurred in three cases $(0.9 \%)$ and seven fetal and neonatal deaths $(2.1 \%)$ were reported. Conclusion. The overall prevalence of prenatal ultrasound screening in our cohort is $74.5 \%$, but often the opportunity for prenatal ultrasonography in the first trimester is missed. In general, the aim should be to offer prenatal ultrasonography in the first trimester in all pregnancies. This allows early reassurance or if fetal disease is suspected, further steps can be taken.

\section{Introduction}

The majority of women living with HIV are in their reproductive years (ages 15-49) [1,2]. The dramatic decrease in the risk of mother-to-child HIV transmission (MTCT) is leading to normality in the lives of couples affected by HIV, who want own children. In Europe, the reduction in MTCT to less than $1 \%$ is mainly due to highly active antiretroviral therapy (HAART). Effective HAART is resulting in suppressed viral load (VL); thus, a vaginal birth can be as safe as a planned caesarean section $[3,4]$. Avoidance of breastfeeding and postnatal neonatal postexposure prophylaxis (PEP) further supports the effective reduction in MTCT [3-5]. Still there is a fear of higher pregnancy complications in women living with HIV [6]. The literature suggests that there is no increased rate of fetal malformations due to the HIV infection or HAART $[6,7]$. A pregnant woman with HIV infection usually has intensified prenatal care including referral for prenatal ultrasound screening [8].

Prenatal ultrasound screening is being offered earlier and earlier [9]. Large studies of noninvasive prenatal screening have already indicated that it will lead to a decrease of invasive prenatal screening procedures such as amniocentesis (AC) or chorionic villi biopsy (CVS) [10]. If invasive prenatal testing 
TABLE 1: Maternal and neonatal characteristics.

\begin{tabular}{|c|c|}
\hline Characteristics & $\begin{array}{c}\text { Value } \\
\text { (total pregnancies } n=330, \\
\text { total newborns } n=338 \text { ) }\end{array}$ \\
\hline Maternal age at delivery $( \pm S D)$ & $31.05 \pm 5.7$ \\
\hline Gravidity & $N=326$ \\
\hline 1 & $89(27.3 \%)$ \\
\hline 2 & $104(31.9 \%)$ \\
\hline 3 & $71(21.8 \%)$ \\
\hline 4 & $38(11.7 \%)$ \\
\hline$\geq 5$ & $24(7.2 \%)$ \\
\hline Parity & $N=326$ \\
\hline 1 & $162(49.7 \%)$ \\
\hline 2 & $108(33.1 \%)$ \\
\hline 3 & $36(11 \%)$ \\
\hline 4 & $12(3.7 \%)$ \\
\hline$\geq 5$ & $8(2.4 \%)$ \\
\hline $\begin{array}{l}\text { Duration of pregnancy (weeks of } \\
\text { gestation) }\end{array}$ & $N=334$ \\
\hline $24+0-33+6$ & $32(9.6 \%)$ \\
\hline $34+0-36+6$ & $90(26.9 \%)$ \\
\hline$>37+0$ & $212(63.5 \%)$ \\
\hline Ethnicity & $N=283$ \\
\hline Caucasian & $95(33.6 \%)$ \\
\hline African & $188(66.4 \%)$ \\
\hline HIV diagnosis during pregnancy & $N=327$ \\
\hline Yes & $79(24.2 \%)$ \\
\hline No & $243(75.8 \%)$ \\
\hline Mode of delivery & $N=332$ \\
\hline Planned caesarean section & $257(77.4 \%)$ \\
\hline Caesarean section in labor & $30(9 \%)$ \\
\hline Emergency caesarean section & $1(0.3 \%)$ \\
\hline $\begin{array}{l}\text { Caesarean section after trial of } \\
\text { vaginal birth }\end{array}$ & $13(3.9 \%)$ \\
\hline Spontaneous vaginal delivery & $29(8.7 \%)$ \\
\hline Unplanned vaginal delivery & $1(0.3 \%)$ \\
\hline $\begin{array}{l}\text { Operative vag delivery } \\
\text { (e.g., forceps) }\end{array}$ & $1(0.3 \%)$ \\
\hline $\mathrm{CD} 4$ count at delivery (cells $/ \mu \mathrm{L})$ & $N=281$ \\
\hline$<200$ & $30(10.5 \%)$ \\
\hline $200-349$ & $76(27 \%)$ \\
\hline$\geq 350$ & $175(62.5 \%)$ \\
\hline Viral load at delivery (copies $/ \mathrm{mL}$ ) & $N=301$ \\
\hline$<50$ & $168(55.8 \%)$ \\
\hline $50-399$ & $88(29.2 \%)$ \\
\hline$\geq 400$ & $45(15 \%)$ \\
\hline $\begin{array}{l}\text { HAART before the beginning of } \\
\text { pregnancy }\end{array}$ & $N=289$ \\
\hline Yes & $181(62.6 \%)$ \\
\hline No & $108(37.4 \%)$ \\
\hline
\end{tabular}

TABLE 1: Continued.

\begin{tabular}{lc}
\hline Characteristics & $\begin{array}{c}\text { Value } \\
\text { (total pregnancies } n=330, \\
\text { total newborns } n=338)\end{array}$ \\
\hline HCV (positive anti-HCV test) & $N=280$ \\
Yes & $25(8.9 \%)$ \\
Negative & $255(91.1 \%)$ \\
\hline 5-min APGAR & $N=330$ \\
$<4$ & 0 \\
$<7$ & $5(1.5 \%)$ \\
$7-10$ & $325(98.5 \%)$ \\
\hline Arterial cord pH & $N=327$ \\
$<7.0$ & 0 \\
$7.0-<7.1$ & $2(0.6 \%)$ \\
$7.1-<7.2$ & $16(4.9 \%)$ \\
$\geq 7.2$ & $309(94.5 \%)$ \\
\hline Base excess $( \pm$ SD) & $N=323$ \\
\hline Weight (g) ( \pm SD) & $-2.98 \pm 2.15$ \\
\hline Percentile & $N=333$ \\
$<10$ th & $2837 \pm 656$ \\
$10-90$ & $N=335$ \\
$>90$ th & $30(9 \%)$ \\
\hline Early anomaly scan $(11+0-14+0$ & $291(86.8 \%)$ \\
weeks of gestation) & $14(4.2 \%)$ \\
\hline Nuchal translucency & $N=100$ \\
\hline Anomaly/detailed scan $20-22$ & $30.5 \%$ \\
weeks of gestation & $N=67$ \\
Anomaly scan any time later in & $20.3 \%$ \\
\hline pregnancy & $N=252$ \\
\hline
\end{tabular}

MTCT: mother-to-child transmission; SD: standard deviation.

is necessary, it can be done, but in these circumstances, HAART should be started prior to the procedure to suppress the VL below the limit of detection. In these cases current, evidence suggests that MTCT is very unlikely; however, studies reporting on the risk of MTCT in invasive prenatal testing are limited due to small study size [11].

HAART is given during pregnancy for two reasons, first to women with an own indication for HAART (they require treatment for their own health) and secondly to pregnant women starting therapy purely as a prophylactic treatment to reduce MTCT.

The aim of our study was to investigate if pregnant HIVpositive women get referred for special prenatal ultrasound screening services in our tertiary referral center, but also if and at what point the prenatal ultrasonography is performed. Pregnant HIV-positive women usually have a combined 
TABLE 2: Maternal and neonatal characteristics according to duration of pregnancy.

\begin{tabular}{|c|c|c|c|c|}
\hline & & n of pregnancy & & \\
\hline & $\begin{array}{c}24+0-33+6 \\
N=32\end{array}$ & $\begin{array}{c}34+0-36+6 \\
N=90\end{array}$ & $\begin{array}{c}37+0-42 \\
N=212\end{array}$ & $P$ value $^{1}$ \\
\hline Maternal age at delivery $( \pm \mathrm{SD})$ & $32.5 \pm 5.8$ & $30.2 \pm 5.8$ & $31.2 \pm 5.6$ & $P=0.102$ \\
\hline Gravidity $n=326$ & & & & $P>0.20$ \\
\hline 1 & $7(24.1 \%)$ & $21(24.7 \%)$ & $68(28.8 \%)$ & \\
\hline 2 & $9(31 \%)$ & $28(32.9 \%)$ & $67(31.6 \%)$ & \\
\hline 3 & 7 (24.1\%) & $19(22.4 \%)$ & $45(21.2 \%)$ & \\
\hline 4 & $3(10.3 \%)$ & $9(10.6 \%)$ & $26(12.3 \%)$ & \\
\hline$>5$ & $3(10.3 \%)$ & $8(10.1 \%)$ & $13(10.7 \%)$ & \\
\hline Parity $n=326$ & & & & $P>0.20$ \\
\hline 1 & $16(55.2 \%)$ & $42(49.4 \%)$ & $104(49.1 \%)$ & \\
\hline 2 & $6(20.7 \%)$ & $30(35.3 \%)$ & $72(34 \%)$ & \\
\hline 3 & $4(13.8 \%)$ & $9(10.6 \%)$ & $23(10.8 \%)$ & \\
\hline 4 & 0 & $3(3.5 \%)$ & $9(4.2 \%)$ & \\
\hline$>5$ & $3(10.3 \%)$ & $1(1.2 \%)$ & $4(1.8 \%)$ & \\
\hline Ethnicity $n=283$ & & & & $P>0.20$ \\
\hline Caucasian & $5(22.7 \%)$ & $27(38.6 \%)$ & $63(33 \%)$ & \\
\hline African & $17(77.3 \%)$ & $43(61.4 \%)$ & $128(67 \%)$ & \\
\hline HIV diagnosis during pregnancy $n=327$ & & & & $P>0.20$ \\
\hline Yes & $9(30 \%)$ & $19(22.1 \%)$ & $51(24.2 \%)$ & \\
\hline No & $21(70 \%)$ & $67(77.9 \%)$ & $160(75.88 \%)$ & \\
\hline Mode of delivery $n=332$ & & & & $P<0.001$ \\
\hline Planned caesarean section & $26(83.87 \%)$ & $70(78.6 \%)$ & $161(75.94 \%)$ & \\
\hline Caesarean section during labor & $5(16.13 \%)$ & $15(16.85 \%)$ & $10(4.72 \%)$ & \\
\hline Emergency caesarean section & 0 & 0 & $1(0.47 \%)$ & \\
\hline Caesarean section after trial of vag birth & 0 & 0 & $13(6.13 \%)$ & \\
\hline Spontaneous vaginal delivery & 0 & $3(3.37 \%)$ & $26(12.26 \%)$ & \\
\hline Unplanned vaginal delivery & 0 & $1(1.12 \%)$ & 0 & \\
\hline Instrumental vaginal delivery (e.g., Forceps) & 0 & 0 & $1(0.47 \%)$ & \\
\hline $\mathrm{CD} 4$ count at delivery (cells $/ \mu \mathrm{L}) n=281$ & & & & $P=0.075$ \\
\hline$<200$ & $2(8 \%)$ & $6(8.3 \%)$ & $22(12 \%)$ & \\
\hline $200-349$ & $12(48 \%)$ & $14(19.4 \%)$ & $50(27.2 \%)$ & \\
\hline$>350$ & $11(44 \%)$ & $52(72.2 \%)$ & $112(60.9 \%)$ & \\
\hline Viral load at delivery $($ copies $/ \mathrm{mL}) n=301$ & & & & $P<0.001$ \\
\hline$<50$ & $9(36 \%)$ & $27(34.6 \%)$ & $132(66.7 \%)$ & \\
\hline 50-399 & $7(28 \%)$ & $32(41 \%)$ & $49(24.7 \%)$ & \\
\hline$\geq 400$ & $9(36 \%)$ & $19(24.4 \%)$ & $17(8.6 \%)$ & \\
\hline HAART before beginning of pregnancy $n=289$ & & & & $P>0.20$ \\
\hline Yes & $17(66.7 \%)$ & $41(55.4 \%)$ & $123(65.4 \%)$ & \\
\hline No & $10(33.3 \%)$ & $33(44.6 \%)$ & $65(34.6 \%)$ & \\
\hline HCV (positive anti-HCV test) $n=280$ & & & & $P>0.20$ \\
\hline Yes & $2(8 \%)$ & $10(13.2 \%)$ & $13(7.3 \%)$ & \\
\hline Negative & $23(92 \%)$ & $66(86.8 \%)$ & $166(92.7 \%)$ & \\
\hline $5-\min \operatorname{APGAR} n=330$ & & & & \\
\hline$<4$ & 0 & 0 & 0 & $P<0.001$ \\
\hline$<7$ & $5(17.24 \%)$ & 0 & 0 & \\
\hline $7-10$ & $24(82.75 \%)$ & $90(100 \%)$ & $211(100 \%)$ & \\
\hline
\end{tabular}


TABLE 2: Continued.

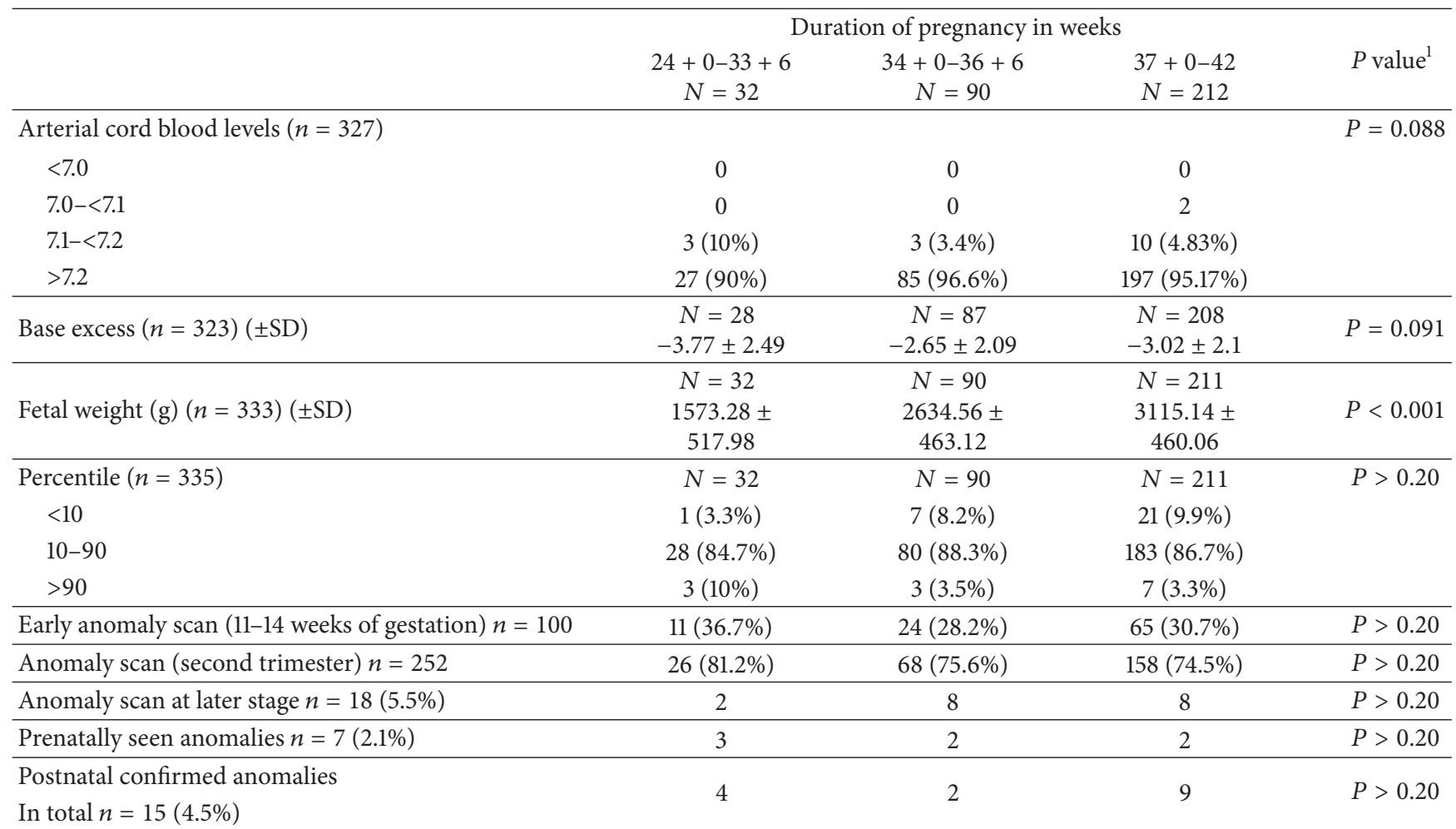

${ }^{1} P$ values were calculated without significance correction. Kruskal-Wallis test was used for maternal age, gravidity and parity, APGAR score, apH, vpH, BE, fetal weight and percentile, fetal length, head circumference, early anomaly scan, anomaly scan. $\mathrm{Chi}^{2}$ test was used for the other characteristics. SD: standard deviation.

antenatal care in a tertiary referral center and with their own gynaecologists.

As well as the prevalence of prenatal ultrasound screening, prenatal, and postnatal finding was recorded. We hypothesized that the fetal anomaly rate in women with HIVinfection is as low as in all other pregnancies $(3-5 \%)[12,13]$.

\section{Materials and Method}

HIV-positive pregnant women who presented in our tertiary referral center between January 1, 2002 and December 31, 2012 were included in this retrospective cohort study.

Only pregnancies $\geq 24$ weeks of gestation were included. Three categories were used: very preterm delivery $(24+0$ to $33+6$ weeks of gestation), preterm delivery $(34+0$ to $36+$ 6 weeks of gestation), and term delivery ( $\geq 37$ weeks of gestation).

All data regarding early prenatal screening (as, e.g., nuchal translucency measurements) and fetal anomaly scan at 20 weeks of gestation or at first presentation in our center were recorded. Only scans which were performed in our center were included, reflecting the fact that HIV-positive pregnant women are high risk pregnancies, and high-risk pregnancies are referred to a tertiary center or an equivalent specialized center for prenatal screening [14-17]. An early anomaly scan was defined as a first trimester scan; in the study period, the fetal nuchal thickness was assessed; a formal nuchal translucency measurement was included if measured by appropriately qualified sonographers. A fetal anomaly scan was defined as a detailed scan in the second trimester (usually between 20 to 22 weeks of gestation). All the scans performed at a later gestation in our department prior to birth are recorded separately as late scans in the third trimester. We collected the abnormal prenatal sonographic findings and compared prenatal with postnatal detected malformations.

Malformations were any fetal/neonatal disease, which required either surgery or special pediatric care including chromosomal anomalies [18]. All cases with an AC, MTCT, and any intrauterine or postnatal death were evaluated.

Maternal information included age, ethnicity, gestational age at delivery, gravidity and parity, HAART already before the pregnancy, VL (copies/mL), CD 4 count (cells/ $\mu \mathrm{L}$ ) prior to birth, and other risk factors such as coinfection with HCV. The last recorded VL prior to the delivery was used and classified in three risk groups. In the study, a VL below 50 is considered as negative/undetectable. The last CD4 count prior to birth was noted, and again three categories were used. The mode of delivery was classified as (1) planned caesarean section; (2) in cases of rupture of membranes and/or contraction it was recorded as elective caesarean section in labour; (3) emergency caesarean section; (4) caesarean section after planned vaginal birth; (5) vaginal birth; (6) unplanned vaginal birth and (7) instrumental vaginal delivery. In the unit the first planned vaginal birth was recorded in 2009. Before that time, women were offered 


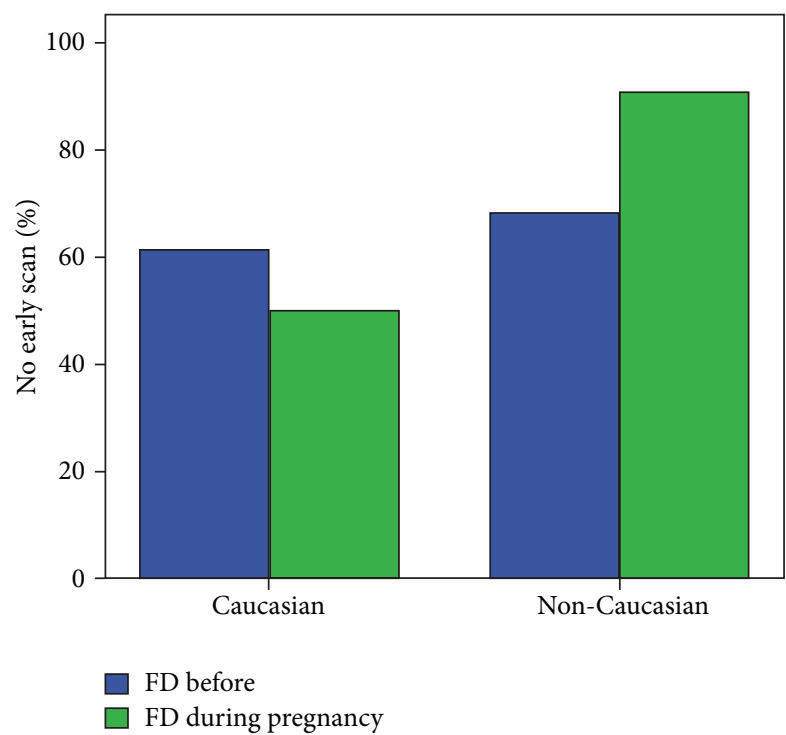

Figure 1: Percentage of women, who had no early scan and factors involved ( $\mathrm{FD}=$ first diagnosis $)$.

elective caesarean section at around $37+0$ weeks of gestation $[3,8,19]$. With evidence for the safety of the vaginal birth with undetectable VL, the policy in the unit shifted towards planned vaginal birth, and if caesarean section was offered in these cases, the delivery was delayed until $>37$ weeks of gestation according to the German-Austrian Guidelines $[3,4,8]$. The following neonatal data were included: APGAR score, arterial cord $\mathrm{pH}(\mathrm{apH})$, cord base excess (BE) and neonatal weight (stratified according to 10th, 10-90th and $>90$ th percentile). A weight below the 10th percentile was considered to be intrauterine growth retardation (IUGR).

Information about scan findings was obtained from the record of the ultrasound department, and further information was collected from maternal case notes, pediatric notes, and discharge letters.

Ethics approval for the retrospective study was obtained from the Ethics Committee at the J. W. Goethe University, Frankfurt (number 30/13).

For categorical variables and nominal variables, frequency tables were used for descriptive statistical analysis. For ordinal and quantitative data, mean and standard deviation (SD) or percentiles were used. These data were further analyzed using the Wilcoxon-Mann-Whitney Test, Kruskal-Wallis Test, Spearman-Correlation, $\mathrm{Chi}^{2}$-Test, and Fisher's Exact Test as appropriate. All tests were 2-sided and a $P$ value below 0.05 was considered statistically significant. In addition, multivariate logistic regression analysis was performed to identify factors associated with a woman having an early anomaly scan.

Statistical analysis was performed using IBM SPSS 20 statistics software.

\section{Results}

Overall 330 pregnancies were recorded, with 322 singleton pregnancies $(97.6 \%)$ and in eight twin gestations (2.4\%).
TABLE 3: Results of multivariate analysis on factors for a woman to have an early anomaly scan.

\begin{tabular}{lccc}
\hline & OR & $95 \%$ CI for OR & $P$ value \\
\hline Ethnicity & 2.008 & $1.155-3.491$ & 0.013 \\
First diagnosis in & 2.085 & $1.033-4.209$ & 0.040 \\
present pregnancy & 0.767 & $0.581-1.013$ & 0.062 \\
Gravity & 1.134 & $0.756-1.702$ & 0.543 \\
Parity & 1.000 & $0.999-1.001$ & 0.710 \\
Birth weight & 0.950 & $0.797-1.133$ & 0.596 \\
\hline
\end{tabular}

OR: odds ratio; CI: confidence interval.

One twin pregnancy was conceived due to IVF with first diagnosis of the HIV-infection in the early second trimester. There were 122 preterm deliveries (36.5\%) and 90 (26.9\%) of these were between 34 and $36+6$ weeks of gestation. Maternal and neonatal characteristics are presented in Table 1, stratified by pregnancy duration in Table 2 .

The mean age at presentation was $31.1 \pm 5.7$ years. Nearly half of all the women (49.7\%) were primiparae. Two thirds of women (66.4\%) were of African ethnicity. In one quarter of women, the diagnosis HIV of infection occurred in the pregnancy. More than three quarters 257 (77.4\%) of the births were elective caesarean section. In 29 cases $(8.7 \%)$, women delivered vaginally. The CD4 count (cells $/ \mu \mathrm{L}$ ) prior to birth was in the majority of $175(62.5 \%) \geq 350$, in $76(27 \%)$ between 200 and 349 , and in $30(10.7 \%)<200$. The VL (copies/mL) in most women 168 (55.8\%) was suppressed below 50 copies in $88(29.2 \%) 50-399$ and in $45(15 \%) \geq 400$. One hundred and eight women $(37.4 \%)$ were on no HAART treatment at the beginning of the pregnancy. In 25 (8.9\%), a positive antiHCV test was recorded. The average weight of the newborn was $2837 \mathrm{~g}( \pm 656)$. Thirty newborns $(9 \%)$ were classified as below the 10th percentile [20].

In 100 of the 330 pregnancies (30.5\%), we did an early ultrasound assessment. The nuchal translucency was measured in 67 (20.3\%) of the 330 cases (NT median $1.22 \mathrm{~mm}$ (range $0.6-3 \mathrm{~mm})$ ). A multivariate analysis for factors influencing a woman having an early anomaly scan (Table 3 ) showed that African ethnicity and first diagnosis of HIV during the ongoing pregnancy were factors which significantly could be related to not having early prenatal ultrasound screening (Figure 1).

Invasive testing (AC) was done in three $(0.9 \%)$ of 330 cases. Only one case was done at 25 weeks in our department, and we started HAART and performed the AC after VL was fully suppressed. The Karyotype was normal. Two cases were done for advanced maternal age without control of VL and without specific precautions for example, HAART, and both revealed a normal Karyotype. In all of three cases, no MTCT occurred.

In the second trimester in 252 (74.5\%) of 330, a detailed anomaly scan at 20-22 weeks was done. In 18 (5.5\%) patients, the scan was performed in the third trimester due to late presentation in our unit. In Table 4, fetal and neonatal malformations as well as chromosomal anomalies are presented. In seven cases of 330 cases (2.1\%), we diagnosed 
TABLE 4: Fetal and neonatal malformation/chromosomal anomalies.

\begin{tabular}{|c|c|c|c|c|c|c|c|c|}
\hline HAART & $\begin{array}{l}\text { Diagnosis } \\
\text { prenatally }\end{array}$ & $\begin{array}{l}\text { Early scan } \\
\quad \text { (first } \\
\text { trimester) }\end{array}$ & $\begin{array}{c}\text { Detailed } \\
\text { scan (second } \\
\text { trimester) }\end{array}$ & $\begin{array}{l}\text { Diagnosis } \\
\text { postnatally }\end{array}$ & $\begin{array}{c}\text { Invasive } \\
\text { testing/Karyotype }\end{array}$ & $\begin{array}{c}\text { Maternal } \\
\text { coinfection }\end{array}$ & $\begin{array}{l}\text { Duration of } \\
\text { pregnancy in } \\
\text { weeks + days }\end{array}$ & Outcome \\
\hline $\begin{array}{l}\text { CBV TDF } \\
\text { T20 }\end{array}$ & $\mathrm{CDH}$ & No & Yes & $\mathrm{CDH}$ & No & $\mathrm{HCV}$ & $36+4$ & $\begin{array}{c}\text { After } \\
\text { operation } \\
\text { alive and well }\end{array}$ \\
\hline CBV NVP & VSD & Yes & Yes & VSD & No & HCV HBV & $33+6$ & MTCT \\
\hline CBV NVP & $\begin{array}{l}\text { Hydrocephalus, } \\
\text { radial deviation } \\
\text { of hands }\end{array}$ & No & Yes & confirmed & $\begin{array}{l}\text { Yes (normal } \\
\text { Karyotype) }\end{array}$ & No & $33+1$ & Died at 1 day \\
\hline CBV NVP & $\begin{array}{l}\text { Dandy Walker } \\
\text { malformation }\end{array}$ & No & Yes & confirmed & $\begin{array}{l}\text { Postnatally } \\
\text { unbalanced } \\
\text { translocation }\end{array}$ & No & $36+1$ & $\begin{array}{l}\text { Died with } 3 \\
\text { months }\end{array}$ \\
\hline TVD AZT & $\begin{array}{c}\text { MCDK Potter } \\
2 \mathrm{a}\end{array}$ & No & Yes & confirmed & Yes & No & $37+1$ & $\begin{array}{l}\text { Alive and } \\
\text { well }\end{array}$ \\
\hline CBV NVP & $\begin{array}{l}\text { Heart defect } \\
\text { (ASD and } \\
\text { dextrocardia) }\end{array}$ & No & Yes & confirmed & No & No & $37+5$ & $\begin{array}{l}\text { Alive and } \\
\text { well }\end{array}$ \\
\hline $\begin{array}{l}\text { TDF NVP } \\
\text { 3TC }\end{array}$ & No & Yes & Yes & $\begin{array}{c}\text { Skin tag } \\
\text { (manubrium) }\end{array}$ & No & No & $37+3$ & $\begin{array}{l}\text { Alive and } \\
\text { well }\end{array}$ \\
\hline TVD AZT & No & Yes & Yes & $\begin{array}{l}\text { Skin tag } \\
\text { (finger) }\end{array}$ & No & No & $36+1$ & $\begin{array}{l}\text { Alive and } \\
\text { well }\end{array}$ \\
\hline TVD AZT & No & No & Yes & $\begin{array}{l}\text { Skin tag } \\
\text { (finger) }\end{array}$ & No & $\mathrm{NO}$ & $37+714$ & $\begin{array}{l}\text { Alive and } \\
\text { well }\end{array}$ \\
\hline TVD NVP & No & No & Yes & ASD & No & No & $37+1$ & $\begin{array}{c}\text { Alive and } \\
\text { well }\end{array}$ \\
\hline $\begin{array}{l}\text { TZV TDF } \\
\text { RAL RTV } \\
\text { DRV } \\
\end{array}$ & No & Yes & Yes & $\begin{array}{l}\text { Oesophageal } \\
\text { atresia }\end{array}$ & No & $\begin{array}{l}\text { Osophageal } \\
\text { correction } \\
\text { postnatally }\end{array}$ & 33 & $\begin{array}{l}\text { Alive and } \\
\text { well }\end{array}$ \\
\hline $\begin{array}{l}\text { AZT TVD } \\
\text { LPV }\end{array}$ & No & No & Yes & VSD & No & No & $41+3$ & $\begin{array}{c}\text { Alive and } \\
\text { Well }\end{array}$ \\
\hline $\begin{array}{l}\text { AZT TVD } \\
\text { SQV RTV } \\
\end{array}$ & No & No & Yes & Trisomy 21 & Yes, postnatally & No & $38+0$ & $\begin{array}{c}\text { Alive and } \\
\text { well }\end{array}$ \\
\hline $\begin{array}{l}\mathrm{LPV} / \mathrm{r} 3 \mathrm{TC} \\
\mathrm{TDF} \text { AZT }\end{array}$ & No & No & Yes & $\begin{array}{l}\text { Trisomy } 21 \\
\text { VSD and } \\
\text { small ASD }\end{array}$ & Yes, postnatally & No & $32+4$ & $\begin{array}{l}\text { Alive and } \\
\text { well }\end{array}$ \\
\hline $\begin{array}{l}\text { TVD } \\
\mathrm{LPV} / \mathrm{r}\end{array}$ & No & Yes & Yes & Omphalocele & No & No & $38+3$ & $\begin{array}{c}\text { Alive and } \\
\text { well }\end{array}$ \\
\hline $\begin{array}{l}\text { TVD } \\
\mathrm{LPV} / \mathrm{r}\end{array}$ & No & Yes & Yes & $\begin{array}{c}\text { Sucking } \\
\text { blister }\end{array}$ & No & No & $37+4$ & $\begin{array}{l}\text { Alive and } \\
\text { well }\end{array}$ \\
\hline $\begin{array}{l}\text { NVP } \\
\text { TVD }\end{array}$ & No & Yes & Yes & $\begin{array}{c}\text { Nevus } \\
\text { sebaceous }\end{array}$ & No & No & $37+2$ & $\begin{array}{l}\text { Alive and } \\
\text { well }\end{array}$ \\
\hline
\end{tabular}

${ }^{1} 46, \mathrm{xy}, \operatorname{der}(5) \mathrm{t}(3 ; 5)(\mathrm{p} 25.1 \mathrm{p} 15.31)$.

46,xy,der(5)(5pter>5p15.31:3p25.1>3pter).

CDH: congenital diaphragmatic hernia; ASD: atrial septal defect; VSD: ventricular septal defect; MCDK: multicystic dysplastic kidney disease (Potter II); CBV: zidovudin/lamivudin; TDF: tenofovir; T20: enfuvirtide; NVP: nevirapin; AZT: zidovudin; 3TC: lamivudin; RAL: raltegravir; DRV: darunavir; SQV: saquinavir; RTV: ritonavir; TVD: tenofovir/emtricitabin; LPV/r: lopinavir/ritonavir.

a fetal malformation. There was no apparent coincidence with HAART or any other recurrence of fetal malformation. Postnatally, all of the seven cases were confirmed, and eight further malformations and two cases with trisomy 21 were detected. The chromosomal anomalies were not suspected. Both women, 33 and 39 years of age, had no early scan or biochemical screening but a scan in our unit (late in the second trimester with no anomalies seen). There were three cases with a skin tag, one nevus sebaceous of the occiput, and one case with a socalled sucking blister on the hand, all considered to be minor. Each of these cases had at least one scan in our department prior to the birth. However, the sucking blister and the nevus were leading to an upgrade in neonatal PEP due to breaking down of protective skin barrier, and one newborn presented with a small omphalocele which was not seen prior to birth. All of these babies were born by 
TABLE 5: Neonatal Mortality.

\begin{tabular}{|c|c|c|c|c|c|}
\hline Year & Mode of delivery & $\begin{array}{c}\text { Gestational age } \\
\text { at delivery }\end{array}$ & Death & HAART & $\begin{array}{c}\text { Fetal/neonatal } \\
\text { disease }\end{array}$ \\
\hline 2003 & $\begin{array}{c}\text { Planned caesarean } \\
\text { section }\end{array}$ & $33+1$ & $\begin{array}{c}\text { First day of } \\
\text { life }\end{array}$ & $\begin{array}{l}\text { CBV NVP EFV } \\
\text { in First } \\
\text { trimester }\end{array}$ & $\begin{array}{c}\text { Complex fetal } \\
\text { anomaly } \\
\text { (hydrocephalus, } \\
\text { radial deviation) }\end{array}$ \\
\hline 2003 & $\begin{array}{c}\text { Planned caesarean } \\
\text { section }\end{array}$ & $36+1$ & 3 months & CBV NVP & $\begin{array}{c}\text { Dandy Walker } \\
\text { malformation } \\
\text { Chromosomal } \\
\text { anomaly }^{1} \\
\end{array}$ \\
\hline 2007 & $\begin{array}{c}\text { Planned caesarean } \\
\text { section (twins) }\end{array}$ & $32+2$ & 9 months & AZT TVD & $\begin{array}{c}\text { Sudden infant } \\
\text { death }\end{array}$ \\
\hline 2008 & $\begin{array}{l}\text { Laparotomy (uterine } \\
\text { rupture) and } \\
\text { hysterectomy due to } \\
\text { placenta percreta }\end{array}$ & $37+6$ & $\begin{array}{c}\text { Intrauterine } \\
\text { death }\end{array}$ & $\begin{array}{c}\text { AZT RTV SQV } \\
\text { 3TC }\end{array}$ & $\begin{array}{c}\text { Intrauterine } \\
\text { death }\end{array}$ \\
\hline 2008 & $\begin{array}{l}\text { Laparotomy and } \\
\text { caesarean section }\end{array}$ & $25+2$ & 1 day & KVX NVP & $\begin{array}{c}\text { Uterine rupture } \\
\text { after } \\
\text { fibroidectomy } \\
\text { prior to } \\
\text { pregnancy }\end{array}$ \\
\hline 2009 & $\begin{array}{c}\text { Planned caesarean } \\
\text { section }\end{array}$ & $29+3$ & 4 weeks & AZT TVD & Volvulus \\
\hline
\end{tabular}

${ }^{1} 46, x y, \operatorname{der}(5) \mathrm{t}(3 ; 5)(\mathrm{p} 25.1 \mathrm{p} 15.31)$.

46,xy,der(5) (5pter>5p15.31:3p25.1>3pter).

CBV: zidovudin/lamivudin; NVP: nevirapin; EFV: efavirenz; AZT: zidovudin; TVD: tenofovir/emtricitabin; RTV: ritonavir; SQV: saquinavir; 3TC: lamivudin; KVX: abacavir/lamivudin.

TABLE 6: Mother-to-child transmission.

\begin{tabular}{|c|c|c|c|c|c|c|}
\hline Year & Mode of delivery & Gestational age at delivery & VL at delivery & Risk of transmission & HAART & Coinfection \\
\hline 2003 & Planned caesarean section & $33+6$ & 90 & High & CBV NVP & HCV HBV \\
\hline 2004 & Planned caesarean section & $36+4$ & 1900 & Medium & CBV NVP & No \\
\hline 2010 & Planned caesarean section & $36+3$ & 4830 & Medium & NVP TVD T20 & No \\
\hline
\end{tabular}

CBV: zidovudine/lamivudin; NVP: nevirapine; TVD, tenofovir/emtricitabin; T20: enfuvirtide.

HCV: hepatitis C; HBV: hepatitis B.

elective caesarean section. The overall fetal malformation rate (including the minor anomalies) was 4.5\% [18].

In Table 5, the fetal and postnatal mortalities are recorded. In our cohort, we had six cases of intrauterine or postnatal loss and all were born by caesarean section. We present in Table 6 the three cases of MTCT. All of the three newborns were delivered by caesarean section, and all were preterm $(33+6,36+3$ and $36+4$ weeks of gestation). In all cases, the VL was detectable, all women were on HAART, and one woman was coinfected with HCV. One woman had already a vertically infected child, and she had a poor compliance.

\section{Conclusion}

There are conflicting results regarding the risks for HIVpositive mothers for possible adverse effects in their pregnancies $[5,6]$. In our study, we confirm the low fetal malformation rate of $4.5 \%$ in women living with HIV. There are different national registers collecting data on HAART and pregnancy outcome (e.g., APR: Antiviral Pregnancy Registry;
NSHPC: National Study of HIV in Pregnancy and Childhood (UK); ECS: European Collaborative Cohort; EPF-French Perinatal Cohort) $[4,21-24]$. These registers confirm the same malformation rate in women taking HAART as in the general population $(3-5 \%)[12,13]$.

Prenatal screening was found to be successful in diagnosing major fetal malformations. The postnatal anomalies were minor ones (skin tag, sucking blister) or missed due to minimal extend (omphalocele). The two cases with postnatal trisomy 21 were missed prenatally but were not seen in typical screening periods. There were no anomalies in the unscreened population.

A change in treatment policies is evident over the 11 years of the study, reflected in the changes in delivery mode over time and the gestational age at delivery [8]. A high preterm delivery rate is confirmed by other groups [6]. In our population, $26.9 \%$ are late preterm deliveries (34-36+ 6 weeks of gestation) and are mostly iatrogenic due to early caesarean section as in other studies and in the past [25]. The updated national German-Austrian Guidelines now delay 
caesarean section to term in women with suppressed VL [8]. The numbers of women with fully suppressed VL $(\mathrm{VL}<50$ copies $/ \mathrm{mL})(P<0.001)$ and CD4 cells $\geq 350(P>0.20)$ prior to birth increased over the last years.

There are two important screening intervals during the prenatal period. The first is early screening which should take place between $11+0$ and $14+0$ weeks of gestation [15]. This early screening was introduced by Nicolaidis in 1992 as a combined method of screening (including ultrasound screening and two maternal biochemical markers: free human chorionic gonadotropin (free hCG $\beta$ ) and pregnancyassociated plasma protein A (PAPP-A) [26-28]. In Germany this test is not covered by the national health system and there for is paid by the woman herself. Usually at that time an early anomaly ultrasound scan can be performed, which is covered by the health system. The second screening interval is the anomaly scan at 20-22 weeks of gestation [17, 29].

The prevalence of first trimester screening of $97.5 \%$ in a low risk general population has been demonstrated [30].

We demonstrate that prenatal screening is offered and available, but that the early screening interval is missed, as only $30.5 \%$ women get referred for early anomaly scan. Even so some women may have chosen not to undergo testing for ethical and cultural reasons. As a limitation of our data it could be that the screening which is done at the communitybased care is missed, but as indicated usually, it warrants a referral to a highly qualified and specially trained team $[16,29]$.

In our study, population the majority of 188 (66.4\%) women were of African origin, and in 79 (24.2\%), the diagnosis $\mathrm{HIV}$-infection occurred in the pregnancy, both factors were significantly related to having no early prenatal screening. Tariq et al. are reporting on late booking for antenatal care in non-Caucasian women compared with caucasian women regardless of time of diagnosis of HIV-infection [31].

Three cases of MTCT are low (0.9\%) and confirmed by other groups (reporting MTCT rates of $0.1 \%-1.3 \%$ ) $[3,4]$. However, looking back in our data, the viral control has improved dramatically over the last 11 years; in $55.8 \%$ of all pregnancies, the $\mathrm{VL}$ is $<50$.

National health systems vary, and a complete first trimester screening (with inclusion of biochemical serum markers) has not been established on a national basis for high risk pregnancies in some European countries. In our cohort, two cases of trisomy 21 occurred, and the question remains open if these two cases could have been traced in a complete first trimester screening. In one pregnancy, an AC was performed due to suspected chromosomal anomaly, which revealed a normal karyotype. It was done after starting HAART and just after the VL was fully suppressed. Due to the time required to initiate HAART and to have a suppressed VL in HIV-positive pregnancies, invasive testing will be very likely to happen in the second trimester which will then raise the difficult ethical questions about late termination of pregnancy when an abnormal result is obtained [32,33]. Data in HIV-positive pregnancies reporting on AC is available [3234]. First trimester screening (including maternal markers as free hCG $\beta$ and PAPP-A) has been investigated in pregnant women living with HIV. Some groups feel that maternal markers could be less reliable than those in HIV-negative women [34, 35]. In our study data from 2002 to 2012, in the first years, the nuchal translucency was assessed but not formally measured. This could be due to the delay in having certified specially trained sonographers involved.

In the future, the new methods of chromosome-selective sequencing of maternal plasma cell-free fetal DNA (cfDNA) in noninvasive prenatal testing (NIPT) are valuable especially for our study group due to no risk of MTCT [27]. At present this interesting method is not widely available, and more data of this new method are needed.

\section{Disclosure}

The authors stated that there are no conflict of interests regarding the publication of this article. Dr. Anke Reitter and Dr. Annette E. Haberl have previously received funding for research, travel grants, consultancy fees, and lecture fees from Bristol-Meyers Squibb and Abbott Laboratories (AR) and for research, travel grants, consultancy fees, and lectures fees from Abbott Laboratories, Boehringer Ingelheim, BristolMeyers Squibb, Gilead, Janssen Merck, and ViiV (AH). Dr. Eva Herrmann served as a Consultant for Roche and Novartis Pharmaceuticals.

\section{Conflict of Interests}

All authors (beside E. Herrmann) belong to the Dreifach Group, which reflects the special interest and expertise in HIV and pregnancy at the J. W. Goethe-University Hospital, Frankfurt.

\section{Acknowledgments}

The authors would like to acknowledge Betty-Anne Daviss and Ken Johnson for writing assistance.

\section{References}

[1] European Centre for Disease Prevention and Control, HIV/AIDS Surveillance in Europe, 2011, http://ecdc.europa. eu/en/publications/publications/20121130-annual-hiv-surveillance-report.pdf.

[2] UNAIDS, UNAIDS Report on the Global AIDS Epidemic, 2012, http://www.unaids.org/en/media/unaids/contentassets/ documents/epidemiology/2012/gr2012/20121120_UNAIDS_Global_Report_2012_en.pdf.

[3] J. Warszawski, R. Tubiana, J. Le Chenadec et al., "Mother-tochild HIV transmission despite antiretroviral therapy in the ANRS french perinatal cohort," AIDS, vol. 22, no. 2, pp. 289299, 2008.

[4] C. L. Townsend, M. Cortina-Borja, C. S. Peckham, A. de Ruiter, H. Lyall, and P. A. Tookey, "Low rates of motherto-child transmission of HIV following effective pregnancy interventions in the United Kingdom and Ireland, 2000-2006," AIDS, vol. 22, no. 8, pp. 973-981, 2008.

[5] K. Aebi-Popp, F. Mulcahy, T. Glass et al., "Pregnant women with HIV on ART in Europe: how many achieve the aim of undetectable viral load at term and are able to deliver vaginally?" 
Journal of the International AIDS Society, vol. 15, supplement 4, p. 18141, 2012.

[6] C. L. Townsend, J. Schulte, C. Thorne et al., "Antiretroviral therapy and preterm delivery-a pooled analysis of data from the United States and Europe," International Journal of Obstetrics and Gynaecology, vol. 117, no. 11, pp. 1399-1410, 2010.

[7] K. M. Knapp, S. B. Brogly, D. G. Muenz et al., "Prevalence of congenital anomalies in infants with in utero exposure to antiretrovirals," The Pediatric Infectious Disease Journal, vol. 31, no. 2, pp. 164-170, 2012.

[8] "German-Austrian recommendations for HIV treatment during pregnancy and for newborns exposed to HIV-update 2008," Deutsche Medizinische Wochenschrift, vol. 134, supplement 1, pp. S40-S54, 2009.

[9] A. Hagen, M. Entezami, A. Gasiorek-Wiens et al., "The impact of first trimester screening and early fetal anomaly scan on invasive testing rates in women with advanced maternal age," Ultraschall in der Medizin, vol. 32, no. 3, pp. 302-306, 2011.

[10] A. Tabor and Z. Alfirevic, "Update on procedure-related risks for prenatal diagnosis techniques," Fetal Diagnosis and Therapy, vol. 27, no. 1, pp. 1-7, 2010.

[11] L. Mandelbrot, C. Jasseron, D. Ekoukou et al., "Amniocentesis and mother-to-child human immunodeficiency virus transmission in the Agence Nationale de Recherches sur le SIDA et les Hépatites Virales French Perinatal Cohort," American Journal of Obstetrics and Gynecology, vol. 200, no. 2, pp. 160.e1-160.e9, 2009.

[12] P. A. Boyd, M. Haeusler, and I. Barisic, "EUROCAT report 9: surveillance of congenital anomalies in Europe 1980-2008," Birth Defects Research A, vol. 91, supplement 1, p. S1, 2011.

[13] B. Khoshnood, R. Greenlees, M. Loane, and H. Dolk, "Paper 2: EUROCAT public health indicators for congenital anomalies in Europe," Birth Defects Research A, vol. 91, supplement 1, pp. S16-S22, 2011.

[14] E. Merz, S. Tercanli, and H. Steiner, "Is ultrasound training in specialized qualified prenatal diagnosis in German-speaking countries still sufficient?" Ultraschall in der Medizin, vol. 34, no. 2, pp. 111-112, 2013.

[15] L. J. Salomon, Z. Alfirevic, C. M. Bilardo et al., "ISUOG practice guidelines: performance of first-trimester fetal ultrasound scan," Ultrasound in Obstetrics \& Gynecology, vol. 41, no. 1, pp. 102-113, 2013

[16] E. Merz, K. Melnel, R. Bald et al., "DEGUM Level III recommendation for "follow-up" ultrasound examination (= DEGUM Level II) in the 11-14 week period of pregnancy," Ultraschall in der Medizin, vol. 25, no. 4, pp. 299-301, 2004.

[17] A. Rempen, "Standards of sonographic examination in early pregnancy-recommendations for the german DEGUM stage III by the German society for the use of ultrasound in medicine (gynaecological and obstetrics section) (DEGUM) and by the working team for ultrasound diagnostics in the German society for gynaecology and ostetrics (DGGG)," Zeitschrift fur Geburtshilfe und Neonatologie, vol. 205, no. 4, pp. 162-165, 2001.

[18] O. P. Heinonen, D. Slone, and S. Shapiro, Birth Defects and Drugs in Pregnancy, PSG Publishing, Littleton, Mass, USA, 1977.

[19] K. Boer, J. F. Nellen, D. Patel et al., “The AmRo study: pregnancy outcome in HIV-1-infected women under effective highly active antiretroviral therapy and a policy of vaginal delivery," International Journal of Obstetrics and Gynaecology, vol. 114, no. 2, pp. 148-155, 2007.

[20] M. Voigt, C. Fusch, D. Olbertz et al., "Analysis of the neonatal collective in the Federal Republic of Germany 12th report: presentation of detailed percentiles for the body measurement of newborns," Geburtshilfe und Frauenheilkunde, vol. 66, no. 10, pp. 956-970, 2006.

[21] J. Sibiude, J. Warszawski, R. Tubiana et al., "Premature delivery in HIV-infected women starting protease inhibitor therapy during pregnancy: role of the ritonavir boost?" Clinical Infectious Diseases, vol. 54, no. 9, pp. 1348-1360, 2012.

[22] A. S. Sturt, E. K. Dokubo, and T. T. Sint, "Antiretroviral therapy (ART) for treating HIV infection in ART-eligible pregnant women," Cochrane Database of Systematic Reviews, no. 3, Article ID CD008440, 2010.

[23] M. Burgard, C. Jasseron, S. Matheron et al., "Mother-to-child transmission of HIV-2 infection from 1986 to 2007 in the ANRS French Perinatal Cohort EPF-CO1," Clinical Infectious Diseases, vol. 51, no. 7, pp. 833-843, 2010.

[24] S. Tariq, C. L. Townsend, M. Cortina-Borja et al., "Use of zidovudine-sparing HAART in pregnant HIV-infected women in Europe: 2000-2009," Journal of Acquired Immune Deficiency Syndromes, vol. 57, no. 4, pp. 326-333, 2011.

[25] K. Aebi-Popp, O. Lapaire, T. R. Glass et al., "Pregnancy and delivery outcomes of HIV infected women in Switzerland 20032008," Journal of Perinatal Medicine, vol. 38, no. 4, pp. 353-358, 2010.

[26] K. H. Nicolaides, G. Azar, D. Byrne, C. Mansur, and K. Marks, "Fetal nuchal translucency: ultrasound screening for chromosomal defects in first trimester of pregnancy," British Medical Journal, vol. 304, no. 6831, pp. 867-869, 1992.

[27] A. B. Sparks, C. A. Struble, E. T. Wang, K. Song, and A. Oliphant, "Noninvasive prenatal detection and selective analysis of cellfree DNA obtained from maternal blood: evaluation for trisomy 21 and trisomy 18," American Journal of Obstetrics and Gynecology, vol. 206, no. 4, pp. 319.el-319.e9, 2012.

[28] M. D. Savvidou, I. Samuel, A. Syngelaki, M. Poulton, and K. H. Nicolaides, "First-trimester markers of aneuploidy in women positive for HIV," British Journal of Obstetrics and Gynaecology, vol. 118, no. 7, pp. 844-848, 2011.

[29] L. J. Salomon, Z. Alfirevic, V. Berghella et al., "Practice guidelines for performance of the routine mid-trimester fetal ultrasound scan," Ultrasound in Obstetrics and Gynecology, vol. 37, no. 1, pp. 116-126, 2011.

[30] K. Spencer, C. E. Spencer, M. Power, C. Dawson, and K. H. Nicolaides, "Screening for chromosomal abnormalities in the first trimester using ultrasound and maternal serum biochemistry in a one-stop clinic: a review of three years prospective experience," International Journal of Obstetrics and Gynaecology, vol. 110, no. 3, pp. 281-286, 2003.

[31] S. Tariq, J. Elford, M. Cortina-Borja, and P. A. Tookey, "The association between ethnicity and late presentation to antenatal care among pregnant women living with HIV in the UK and Ireland," AIDS Care, vol. 24, no. 8, pp. 978-985, 2012.

[32] V. Maiques, A. García-Tejedor, A. Perales, J. Córdoba, and R. J. Esteban, "HIV detection in amniotic fluid samples: amniocentesis can be performed in HIV pregnant women?" European Journal of Obstetrics Gynecology and Reproductive Biology, vol. 108, no. 2, pp. 137-141, 2003.

[33] M. H. Yudin, T. L. Prosen, and D. V. Landers, "Multiple-marker screening in human immunodeficiency virus-positive pregnant women: screen positivity rates with the triple and quad screens," American Journal of Obstetrics and Gynecology, vol. 189, no. 4, pp. 973-976, 2003. 
[34] P. Brossard, M. Boulvain, O. Coll et al., "Is screening for fetal anomalies reliable in HIV-infected pregnant women? A multicentre study," AIDS, vol. 22, no. 15, pp. 2013-2017, 2008.

[35] C. Rudin, A. Spaenhauer, O. Keiser et al., "Antiretroviral therapy during pregnancy and premature birth: analysis of Swiss data," HIV Medicine, vol. 12, no. 4, pp. 228-235, 2011. 


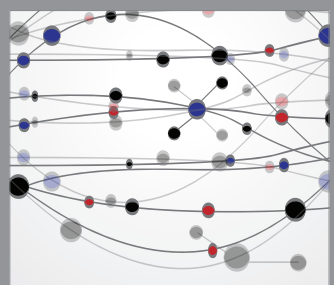

The Scientific World Journal
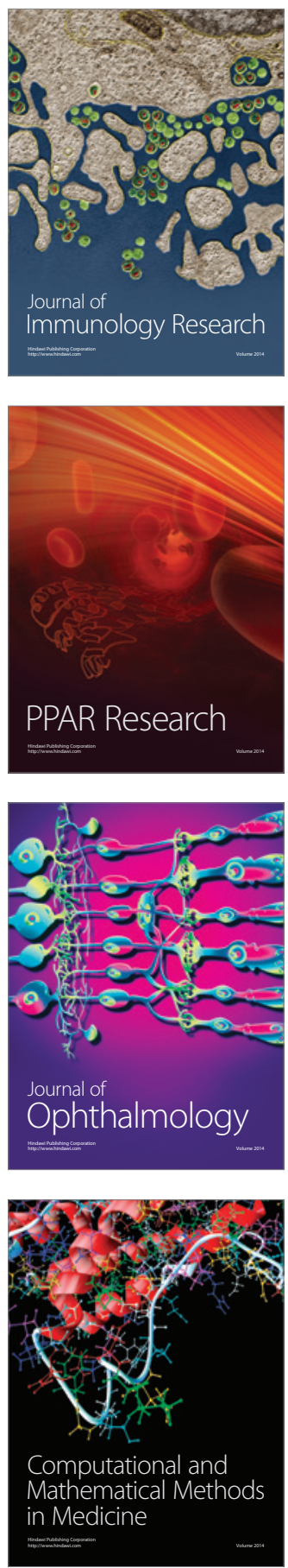

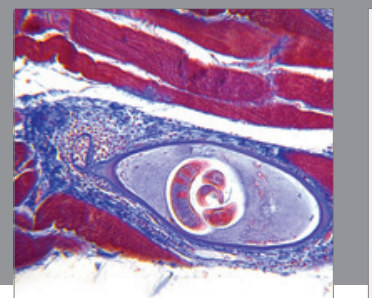

Gastroenterology

Research and Practice
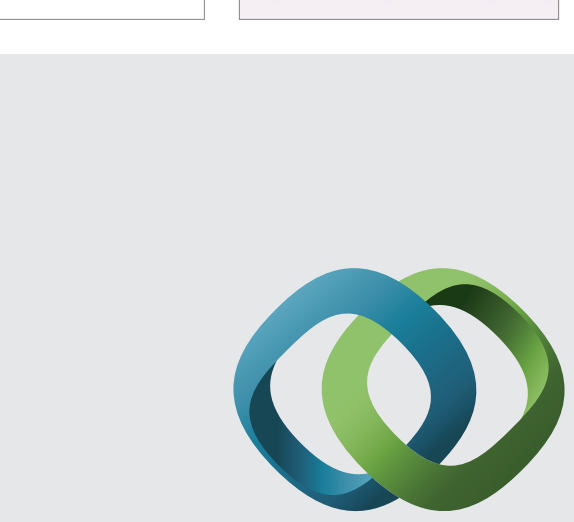

\section{Hindawi}

Submit your manuscripts at

http://www.hindawi.com
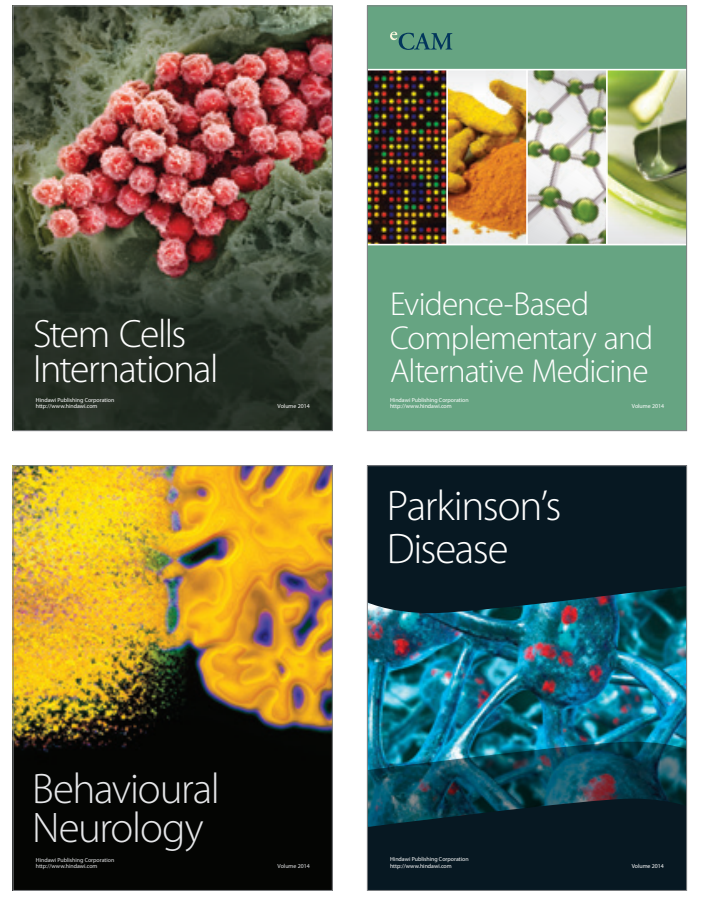
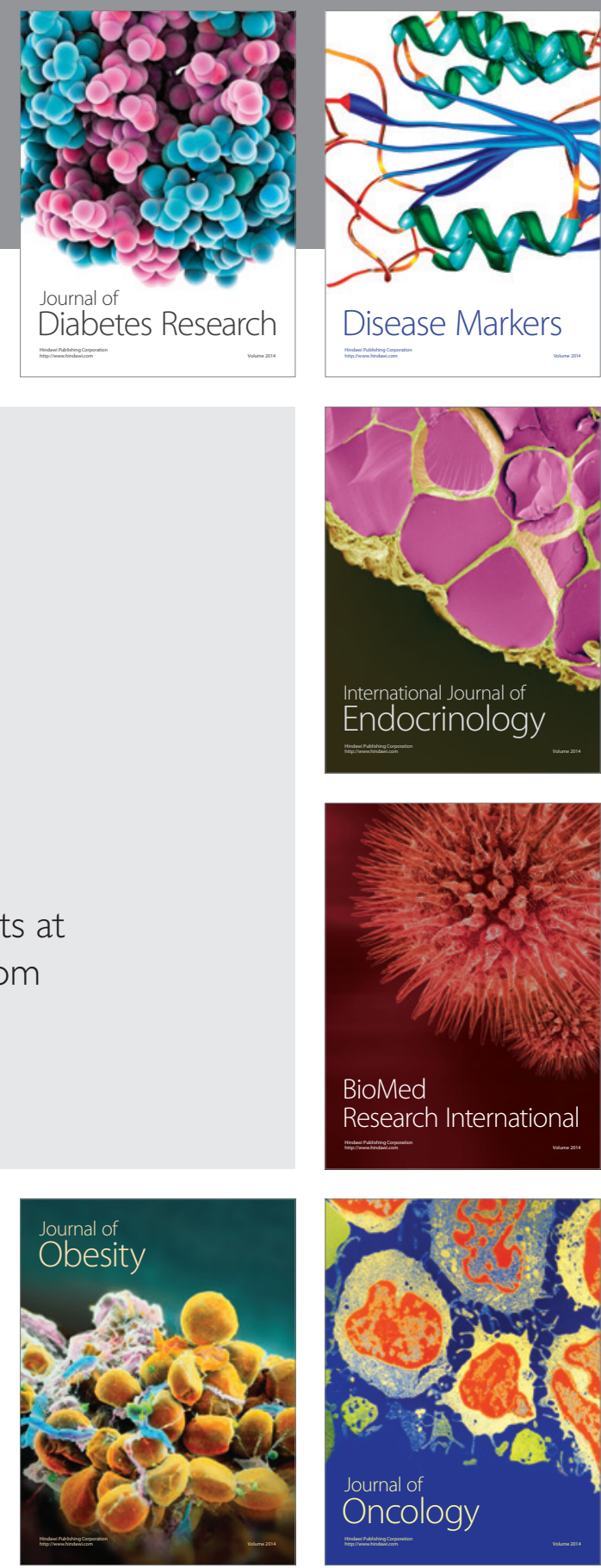

Disease Markers
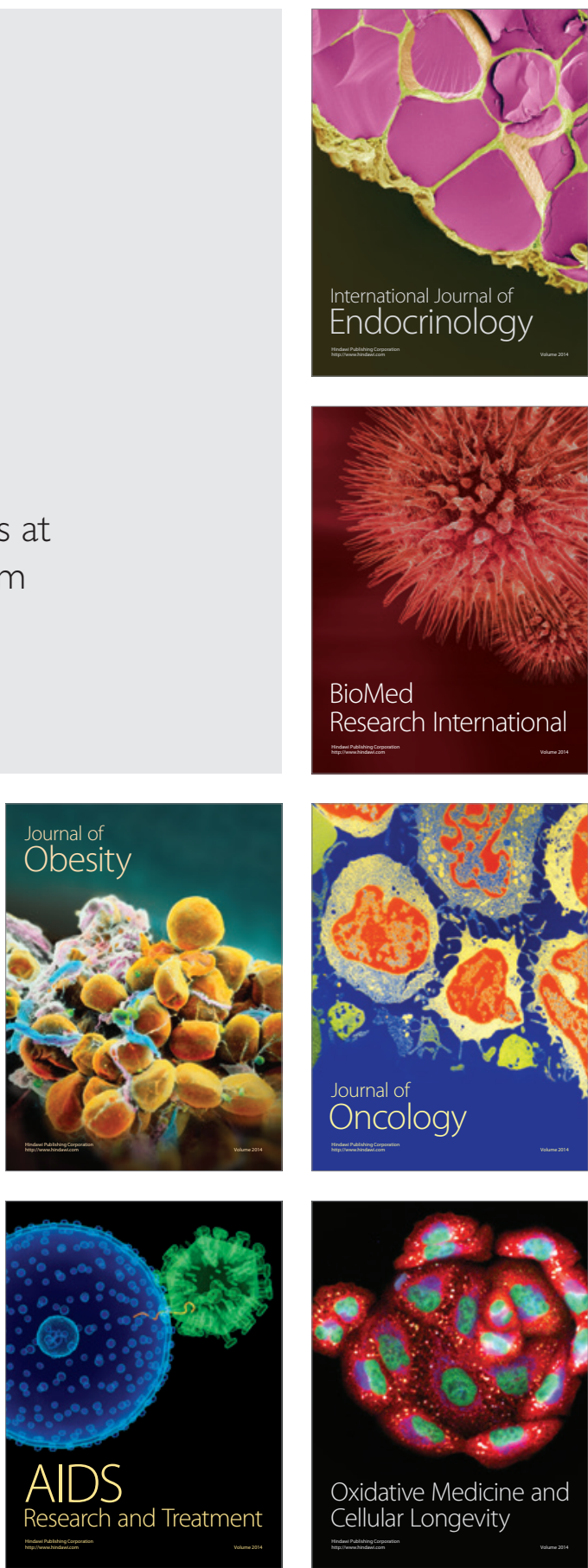